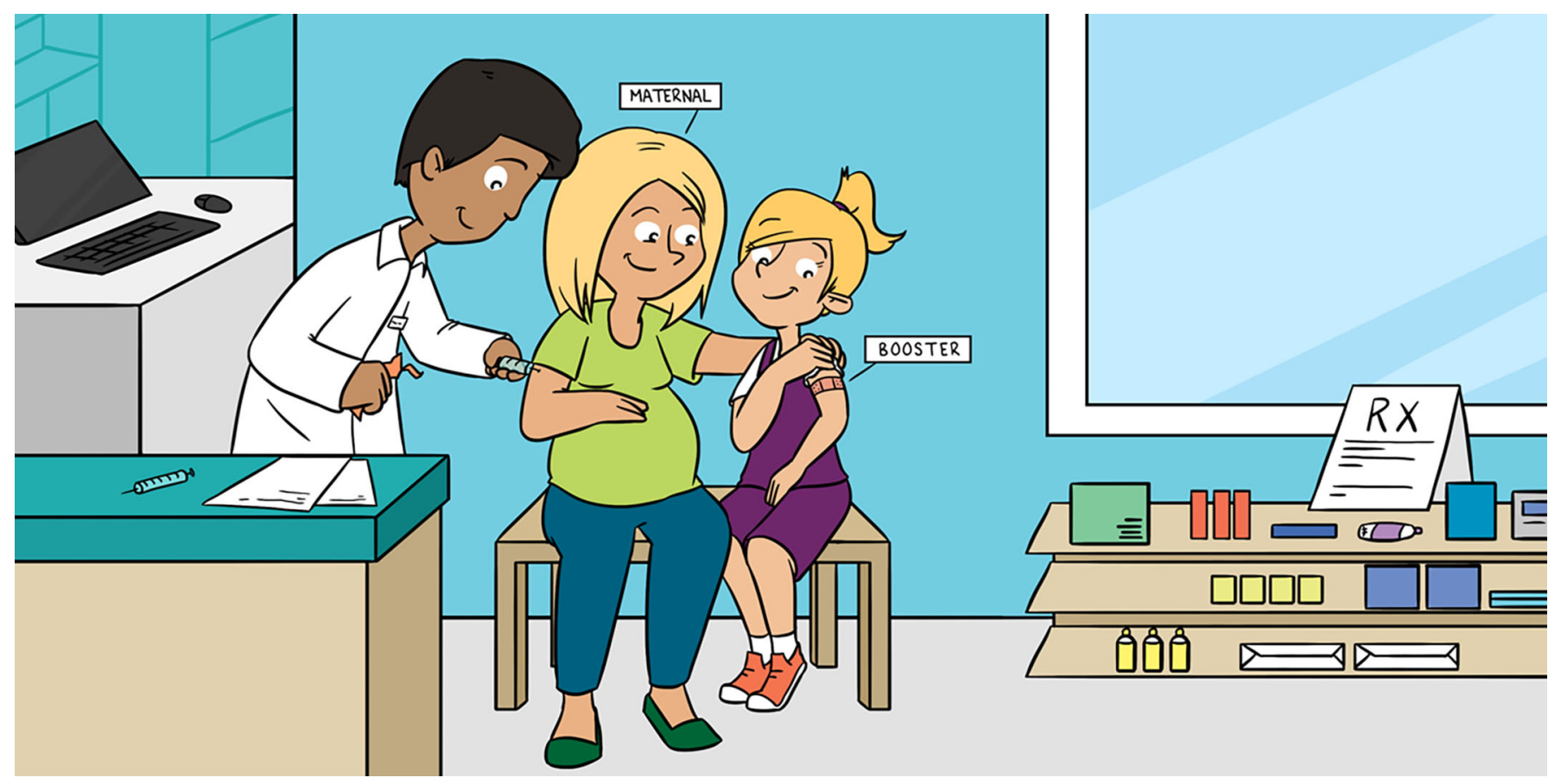

\title{
WHAT IS WHOOPING COUGH AND HOW CAN WE PROTECT OURSELVES?
}

\section{Nicole Guiso *}

Institut Pasteur, Paris, France

\section{YOUNG REVIEWER:}

SAHASRA

AGE: 14
Whooping cough is a very contagious respiratory disease, caused by a bacterium called Bordetella pertussis. Babies $<3$ months of age can die from whooping cough, and it is also particularly dangerous for seniors. Children are protected from whooping cough if they have the tools to eliminate the bacterium when they come in contact with it. These tools are cells and antibodies in the blood, and this protection can be acquired by vaccination. There are two types of vaccines against whooping cough: one contains whole bacteria that have been inactivated by heat or chemicals, and another contains inactivated factors removed from the bacteria. After vaccination with either vaccine, children are protected against the bacterium. However, after several years, the protective cells and antibodies decrease or disappear, and it is important for children to get revaccinated. These revaccinations are called vaccine boosters, and they are recommended for children, adolescents, adults, seniors, and pregnant women. 
Figure 1

The different phases of whooping cough. First, contact with aerosols from an infected person; then the bacteria contained in the aerosols multiply in the trachea and damage it, inducing only very few symptoms like a cold: then the bacteria secrete factors inducing a terrible cough, vomiting, and after a few weeks, the cough will gradually decrease. The disease can last 100 days in a non-vaccinated person.

\section{RESPIRATORY}

\section{DISEASE}

Any of the disorders that affect

human respiration.

\section{AEROSOLS}

Suspensions of liquid in air that are sprayed by infected persons who are coughing.

\section{PERTUSSIS}

The Latin name of whooping cough (Per for intensive and tussis for cough).

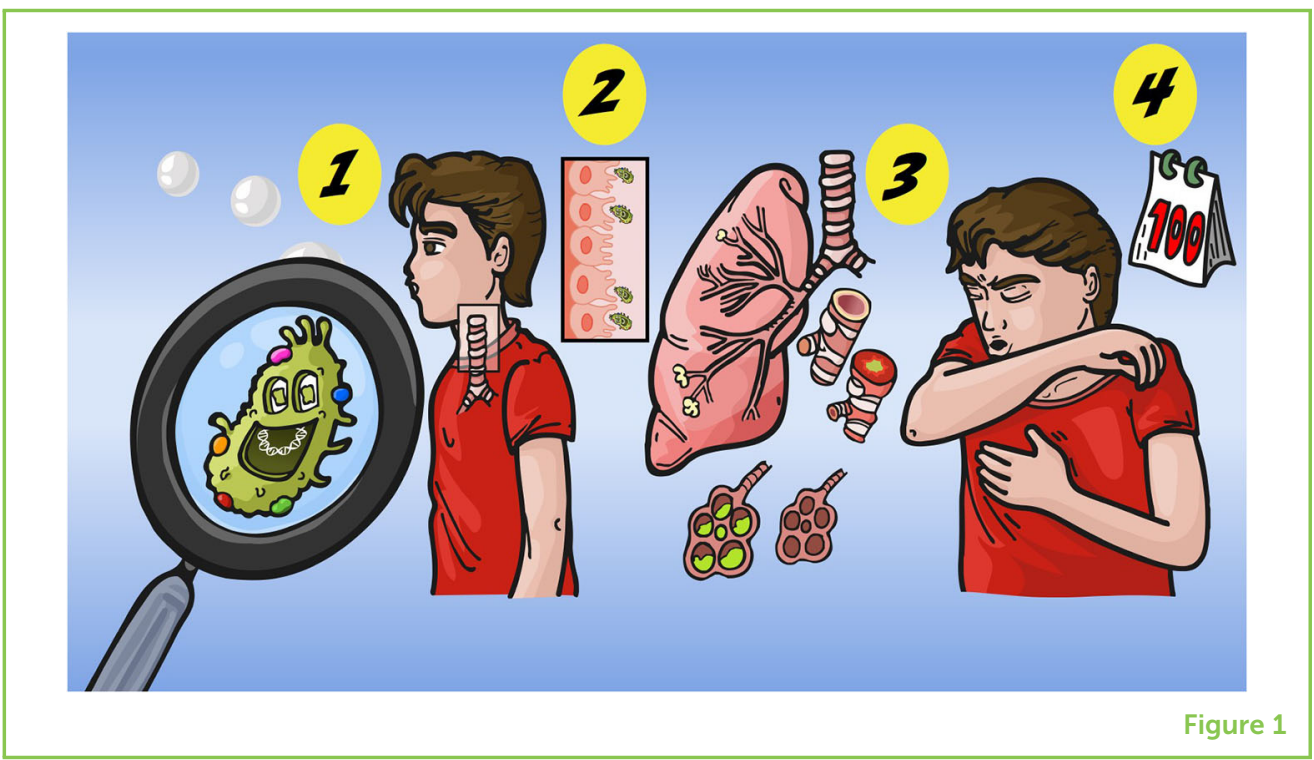

\section{WHAT IS WHOOPING COUGH?}

Whooping cough is a human respiratory disease that spreads very easily between people and affects the human respiration in particular the parts of the respiratory tract, such as the trachea and the lungs. Whooping cough is transmitted by aerosols which are suspensions of liquid in air that are sprayed by infected persons who are coughing. After the bacterium infects a person, it can take around 1 week before the person develops symptoms. When symptoms develop, they include a bad cough and runny nose, kind of like a cold, with no fever. Then the cough gets worse, and people can develop difficulty breathing. The noise that is made because of the breathing difficulty is called the whoop. Vomiting can also result. Symptoms often get worse at night. It takes a long time to recover from whooping cough, with a decrease in whoops and coughing happening slowly over the course of $2-5$ weeks (Figure 1). The symptoms of whooping cough are what give the disease its Latin name, pertussis: "per" means intensive and "tussis" means cough.

Whooping cough can be especially serious and even deadly for babies $<3$ months of age. During the nineteenth century, whooping cough caused 1 out of every 1,000 children to die. It is also dangerous for seniors [1].

\section{WHAT CAUSES WHOOPING COUGH?}

The agent of whooping cough is a bacterium. The bacterium causing this disease was identified in Paris in 1900 by J. Bordet, a Belgium physician and researcher. This bacterium was only isolated and grown in the lab 6 years later, after the development of a special substance on which the bacteria could easily grow outside the body [2]. This 
bacterium was called Bordetella pertussis in honor of its discoverer, J. Bordet.

\section{IS THERE A VACCINE AGAINST WHOOPING COUGH?}

One of the best ways to protect people against an infectious disease is to develop a vaccine. Vaccines can either contain the whole organisms that causes the disease, in a weakened or killed form, a piece of the disease-causing organism, or an inactivated toxin produced by the organism. Because the disease-causing organism is not active, vaccinations do not cause the symptoms normally observed during the disease. Instead, injection of the vaccine causes an immune response in the vaccinated individual. This means that the vaccinated person builds defenses against the disease agent. In the case of whooping cough, these defenses include antibodies that can bind to Bordetella pertussis and eliminate it, as well as cells of the immune system that can kill cells infected by the bacterium. When people are vaccinated they are armed to fight the disease. That means that when they encounter the live, infection-causing bacterium, they will be able to eliminate it quickly without getting sick.

WPV

Whole cell Pertussis Vaccine.

\section{FIRST WHOOPING COUGH VACCINE: A WHOLE CELL VACCINE}

The first vaccine developed against pertussis was made of whole bacteria that had been inactivated by heating or chemicals. This whole cell vaccine was called wPV, which stands for whole pertussis vaccine. This vaccine was given as three injections to babies at 2, 3, and 4 months and one injection at 18 months. The last injection we call a booster, i.e., an injection to boost the immune response of the child.

The pertussis vaccine was combined with the diphtheria and tetanus vaccines and was used in the U.S. starting in 1948. It was a huge success and deaths from whooping cough decreased by $99 \%$. A decade later, wPV was used in Europe with the same success. Due to the success of wPV, in 1977 the World Health Organization created the Expanded Program on Immunization, with the goal of vaccinating all children around the world [3].

However, two decades after universal use of wPV began in the U.S., some bad news emerged. First of all, wPV was found to cause some side effects, such as fever after vaccination, pain and swelling at the site of infection, and problems with the nervous system. Secondly, 25 years after the introduction of vaccination against whooping cough, the number of babies hospitalized for this disease began to increase again. Why? Researchers found that the immune defenses created by WPV decreased as time went on. Before vaccination became a common 
Figure 2

Change of transmission of whooping cough after vaccination of babies before vaccination, around 80 years ago, children were contaminated by contacts with infected children (yellow color around children). After the introduction of vaccination with WPV only for babies and very young children, the mortality decreased a lot and it was a success. However, a change occurred: children were protected against the disease (orange color around the child) but adolescents were not anymore because the protection induced by vaccination is not life-long. Adults did not have any more contact with infected children or babies $<8$ weeks old who cannot be vaccinated yet (yellow color around the family members). Then a new vaccine was developed This aPV vaccine was used to introduce regular boosters for young children, adolescents, adults, and pregnant women in order to protect the whole population as well as babies $<8$ weeks old (orange color).

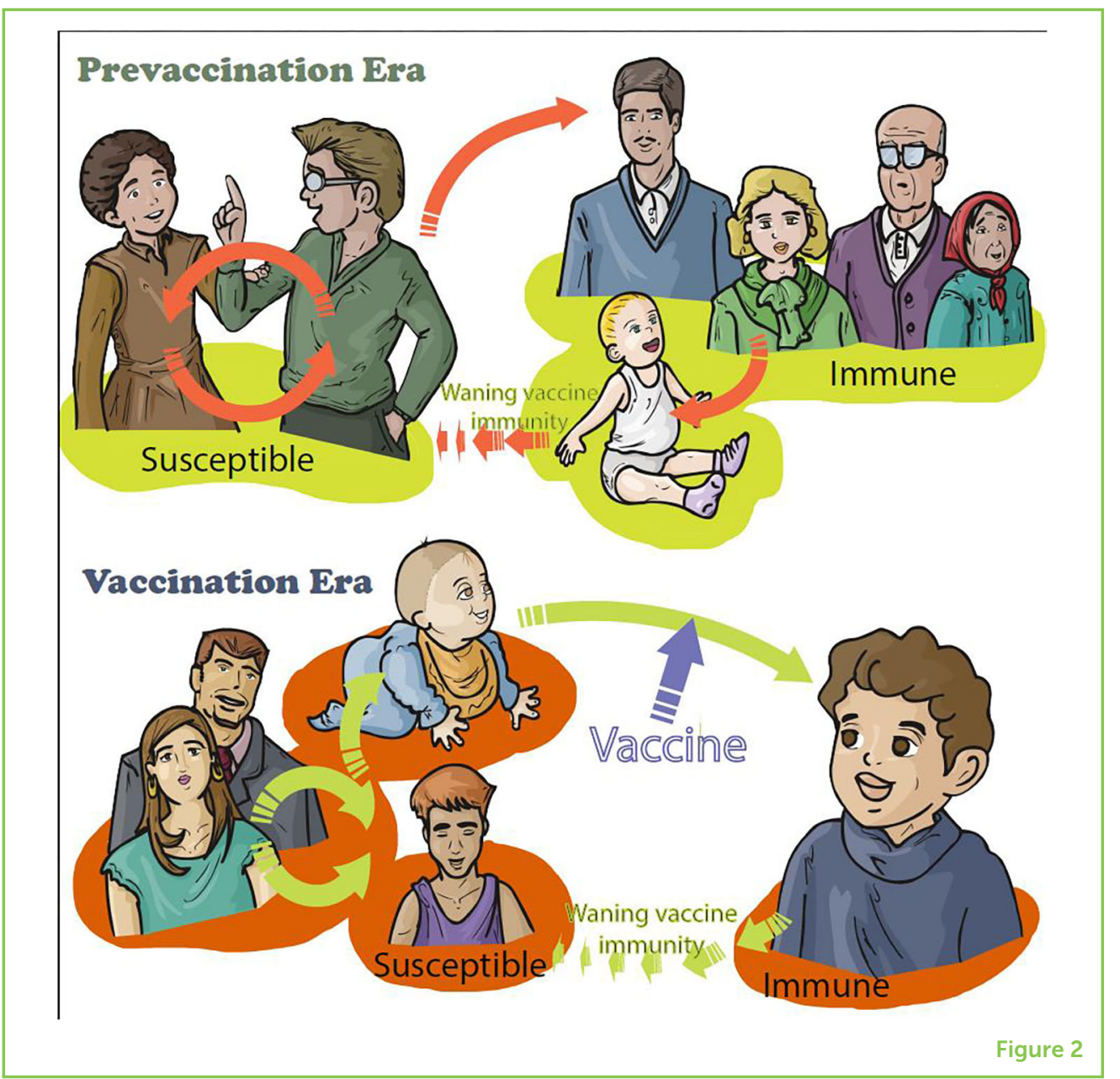

practice, people who survived whooping cough when they were young were often in contact with infected young children, because whooping cough was still common. These contacts stimulated their bodies to produce new immune cells and antibodies as they got older. These stimulations are called natural boosters (Figure 2). However, after vaccination started, people no longer came in contact with children with whooping cough, and without these natural boosters, their immune defenses began to fade. Then, if they did become infected with the bacterium, they could get sick just as if they had never been immunized. The even bigger problem was that infected adults could spread the bacterium to young, unvaccinated babies, for whom the disease is very dangerous (Figure 2).

These observations convinced researchers to try to develop a new type of vaccine against whooping cough-one that had fewer side effects and could be used to boost regularly people whose immune defenses against pertussis were fading, which was not recommended with wPV because of its side effects [4]. 
aPV

Acellular

Pertussis Vaccine.

COCOONING

STRATEGY

Vaccination strategy consisting of vaccinating all persons in contact with a baby before their birth.

\section{SECOND WHOOPING COUGH VACCINE: AN ACELLULAR VACCINE}

The second type of vaccine created against whooping cough is called the acellular pertussis vaccine (aPV), since it is composed only of a few factors produced by the bacterium. To prepare the aPV, it is necessary to purify all these bacterial factors without destroying their structures and then to inactivate them so that they cannot harm people.

After several tests, aPV was found to be as effective as WPV and it caused fewer side effects. This meant that aPV could be used for boosters [3]. A short time after it was developed, aPV booster vaccines for older children, adolescents, and adults were rapidly introduced in Europe, North America, Japan, and Australia, but not in many other parts of the world, because the aPV are expensive. Today, the world is divided in two: the countries using WPV with the old vaccine strategy of vaccinating only young children (mostly Africa, Asia, and South America) and those using aPV with the new vaccine strategy that includes booster vaccinations (Australia, Europe, Japan, and North America).

However, 20 years after the start of vaccinations with aPV, we are again seeing an increase of the number of infants hospitalized with whooping cough, as we saw with wPV. Of course, the number is very low as compared to the time when children were not vaccinated at all, but even one death or 3-weeks hospitalization of a baby is unacceptable!

We now know that the immune protection caused by aPV, similar to that induced by WPV, is not a life-long protection. Vaccine boosters are still extremely important. Today, we are seeing that the protection provided by whooping cough vaccines is not high enough in adolescents and adults. Deaths of young, unvaccinated babies are still occurring: babies cannot be vaccinated before 6-8 weeks of age, and they thus can become infected by their parents, grandparents, siblings, or babysitters before being old enough to get vaccinated.

\section{WHAT CAN BE DONE TO PROTECT BABIES IN 2020?}

Researchers are still trying to develop a new vaccine that can provide longer-lasting protection against whooping cough. In the meantime, it is important to develop new strategies that can be used with the existing vaccines to protect babies between their birth and 8 weeks of age.

One of these is called the cocooning strategy. When a couple decides to have a baby, this strategy consists of vaccinating the future parents 


\section{MATERNAL}

\section{VACCINATION}

Strategy of vaccinating a pregnant woman before the birth of their baby. and all the people who will be in contact with the baby. This includes family members, babysitters, and the medical staff.

Another strategy is called maternal vaccination. This strategy consists of vaccinating the future mother at least 3-4 months before delivery. If the mother is vaccinated, she will produce immune cells and antibodies and will not transmit the disease to the baby. Furthermore, she will transmit part of her immunity to the baby, especially the antibodies. The mother's antibodies will protect the baby for at least 3 months after birth, until the baby is old enough to be vaccinated.

\section{LESSONS LEARNED}

Several important lessons have been learned since the introduction of vaccination against whooping cough. First, we have discovered that: whooping cough is not only a pediatric disease: a person who has not been vaccinated or whose immune defenses have weakened can be infected at any age. We have also learned that vaccination is the best way to be protected against whooping cough, so it is extremely important for all of us to get our vaccines at the recommended times. And lastly, we need to keep an eye out for whooping cough outbreaks, even if we have an effective vaccine. If we are paying attention, we can catch new outbreaks early and change the vaccine strategy if needed-possibly by using techniques like maternal vaccination and cocooning [5].

In conclusions, whooping cough is a very dangerous disease, in particular for babies and seniors. We have effective vaccines able to protect us against the disease. However, the immunity induced by these vaccines is not life-long. It is the reason that the vaccine calendar is regularly adapted by adding vaccine boosters in order to suppress mortality due to this disease. It is therefore very important to follow the vaccination recommendations from the Public Health authorities.

\section{REFERENCES}

1. Heininger, U. 2010. Update on pertussis in children. Expert Rev. Anti Infect. Ther. 8:163-73. doi: 10.1586/eri.09.124

2. Bordet, J., and Gengou, O. 1906. Le Microbe de la coqueluche. Ann. Inst. Pasteur 2:731-41.

3. Guiso, N., Meade, B., and Wirsing Von Koenig, C. H. 2020. Pertussis vaccines: the first hundred years. Vaccine 38:1271-6. doi: 10.1016/j.vaccine.2019.11.022

4. Zepp, F., Heininger, U., Mertsola, J., Bernatowska, E., Guiso, N., Roord, J., et al. 2011. Rationale for pertussis booster vaccination throughout life in Europe. Lancet Infect. Dis. 11:557-70. doi: 10.1016/S1473-3099(11)70007-X

5. World Health Organization. 2015. Pertussis Vaccines: WHO Position Paper. Available online at: https://www.who.int/wer/2015/wer9035 
SUBMITTED: 27 April 2020; ACCEPTED: 03 November 2020;

PUBLISHED ONLINE: 25 November 2020.

EDITED BY: Michel Goldman, Institute for Interdisciplinary Innovation in healthcare (I3h), Belgium

CITATION: Guiso N (2020) What Is Whooping Cough and How Can We Protect Ourselves? Front. Young Minds 8:543329. doi: 10.3389/frym.2020.543329

CONFLICT OF INTEREST: The author declares that the research was conducted in the absence of any commercial or financial relationships that could be construed as a potential conflict of interest.

COPYRIGHT () 2020 Guiso. This is an open-access article distributed under the terms of the Creative Commons Attribution License (CC BY). The use, distribution or reproduction in other forums is permitted, provided the original author(s) and the copyright owner(s) are credited and that the original publication in this journal is cited, in accordance with accepted academic practice. No use, distribution or reproduction is permitted which does not comply with these terms.

\section{YOUNG REVIEWER}

\section{SAHASRA, AGE: 14}

Hello, I am Sahasra, rising tenth grader. I am eagerly waiting to start my high school. I am interested in Science and Language. I love listening to music and reading books. J.K. Rowling is my hero. Playing volleyball is my passion. I play for my school and local club. I would love to pursue my career in life sciences or healthcare.

\section{AUTHOR}

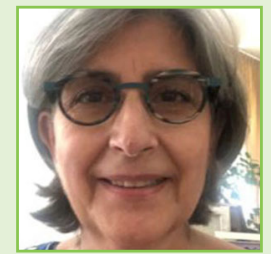

\section{NICOLE GUISO}

Nicole Guiso obtained her Ph.D. and then her Thesis in Microbiology in 1980. She became Director of Researches in 1991. She created and was the Director of the National Pertussis Reference Centre from 1993 till 2015 at the Institut Pasteur in Paris. Nicole Guiso has authored more than 300 articles in international peer-reviewed journals and 20 book chapters. She is presently the President of the Perilic project aiming to build reference laboratories in several Instituts Pasteur around the world. *nicole.guiso@pasteur.fr 